\title{
Preparing teachers for the use of digital technologies in educational activities
}

\author{
Natalia Sheveleva ${ }^{1}$, Dmitriy Mahotin ${ }^{1 *}$, Sergey Lesin $^{2}$, and Oxana Curteva ${ }^{3}$ \\ ${ }^{1}$ Moscow City University, Institute of Continuing Education, Department of Pedagogical \\ Technologies of Continuing Education, Moscow, Russia \\ ${ }^{2}$ Moscow City University, Laboratory of Educational Policy Research, Department of Strategic \\ Growth, Moscow, Russia \\ ${ }^{3}$ Comrat State University, Department of Pedagogy and Psychology, Comrat, Republic of Moldova
}

\begin{abstract}
Digital technologies have a strong impact on changes in the educational environment and activities. In the context of such changes, aggravated by the spread of coronavirus infection and the transition of schools to distance learning, teachers and students are facing the need to actively master digital tools and educational platforms. The authors aim at analyzing the professional gaps of teachers associated with digital literacy and the ability to effectively use digital technologies in educational activities. The conducted sociological research and the results obtained allow the authors to study the existing internal teachers' gaps and show the main problems in the organization of educational activities in the context of the transition to distance learning and the existing gaps in the use of digital technologies by school teachers. Based on the results of the study, the authors have identified the key areas of the professional development of teachers. They have developed educational programs aimed at skill development and further training of teachers in the Russian Federation and foreign countries on such topics as the digital educational environment and the use of open educational resources, methods of using digital technologies in the organization of educational activities, methods and techniques of organization feedback, pedagogical communication in the digital environment, and information security and ethics in the digital environment. The authors have determined the conditions for the professional development of teachers in the process of skill development and further training, as well as self-education (including spontaneous training in the workplace).The authors believe that the increase in teachers' digital literacy, based on filling their professional gaps, will help to improve the quality of general education and create conditions for the elimination of the digital divide of the population.
\end{abstract} Keywords: digital technologies, digital didactics, digital divide, professional development of teachers.

\footnotetext{
*Corresponding author: mahotinda@mgpu.ru
} 


\section{Introduction}

The changes in the school educational environment appear due to the influence of digital technologies, which create new opportunities in the organization of educational activities. On the other hand, the sudden transition to distance learning, which is connected with the pandemic, has caused other challenges for teachers, students, and parents. This is the solution of not only technical, organizational, and pedagogical problems, but also the problems of the meta subject level, such as the organization of educational activities, the formation of educational motivation, self-control, and the mastery of digital tools and services $[1,2,3]$.

In these conditions, teachers face several requirements and restrictions on the organization of educational activities and redesign each lesson and cycle of educational activities, using and mastering digital technologies.

The experience of the Moscow City University in the process of skills development and further training of teachers in Moscow, Moscow region, and Novgorod region showed that the process of digitalization of educational activities in the organization of the pedagogical activity of a teacher should be considered from several aspects. Firstly, the digitalization of the educational environment. It is necessary to consider the formation of a high-quality electronic educational environment where the online platform, through which educational activities are implemented, will play an important role. Secondly, the digitalization of educational content and providing communication with the formation of interactive content and its use in the classroom (synchronous and asynchronous format). Thirdly, the digital features of pedagogical communication and organizational and pedagogical aspects. It is necessary to learn how to choose a digital instrument of pedagogical communication correctly and accurately and understand the regulations for its use in specific conditions. Finally, security in the digital environment.

Thus, it is important to speak about the possibilities of digital technologies and the developing digital educational environment of the modern school, as well as professional gaps that arise during the massive transition to the use of digital technologies in the context of online learning and distance support [4].

The main aim of the study is to analyze the professional gaps of teachers associated with digital literacy and the ability to effectively use digital technologies in educational activities. Based on this study and the experience of mass skill development and further training of teachers in the field of digital tools and services, the main principles and directions of such training of teachers are put forward.

\section{Methods}

In the 2019-2020 school year, a sociological study became the main tool for analyzing the existing professional gaps of teachers. The study involved more than 600 respondents (teachers from Moscow schools) and included 24 questions aimed at determining the existing professional gaps.

\section{Results}

The results of the study showed that according to most teachers, the following aspects influence the quality of educational results: professionalism, a child's ability, involvement of parents, feedback importance, and the organization of a safe and well-organized school environment. Such aspects as the right to choose programs independently, techniques and methods, and tutor support were mentioned less frequently. The teachers did not have a 
clear understanding of the importance of feedback and the use of individualization methods and techniques $[5,6,7]$.

Feedback helps teachers to achieve high efficiency during the lessons, taking into account personal needs and requests; it provides an opportunity to change the direction of the formation and development of skills and abilities [8]. Due to feedback, the interpersonal interaction according to the models "teacher-student" and "teacher-parent" is carried out. However, the survey participants did not consider the importance of feedback as a priority in shaping the quality of education.

According to researchers, the value of constructive feedback is in the fact that the teacher communicates with the child, which is aimed at achieving the necessary results not only in education but also in the development of personal qualities that contribute to increasing motivation, ensuring conscious activity in achieving objective results. When students have insights that help to understand the essence of the studied phenomena and processes this is the result of effectively organized feedback $[9,10]$. On the other hand, the development of the child depends not only on this but also on teachers and parents, if they are interested in the child's success $[11,12]$.

As part of the study, the respondents were asked an open-ended question with a list of some feedback types and a request to indicate other types used (Figure 1). Google-forms and Zoom were indicated; other types contextually duplicated those that were mentioned in the survey. $87.7 \%$ of the teachers reported that they used oral individual conversation as feedback. Only $57.1 \%$ used messengers (WhatsApp, Viber, Telegram, etc.). 53.3\% used written messages in an electronic grade book, $38.1 \%$ used e-mails, and $13.3 \%$ used social networks. A third of the respondents indicated that they used conversation at a parentteacher meeting as a type of feedback with students. $7.5 \%$ used teacher council, possibly referring to inviting students and parents to such meetings, which tend to be nonconstructive.

\section{Types of feedback}

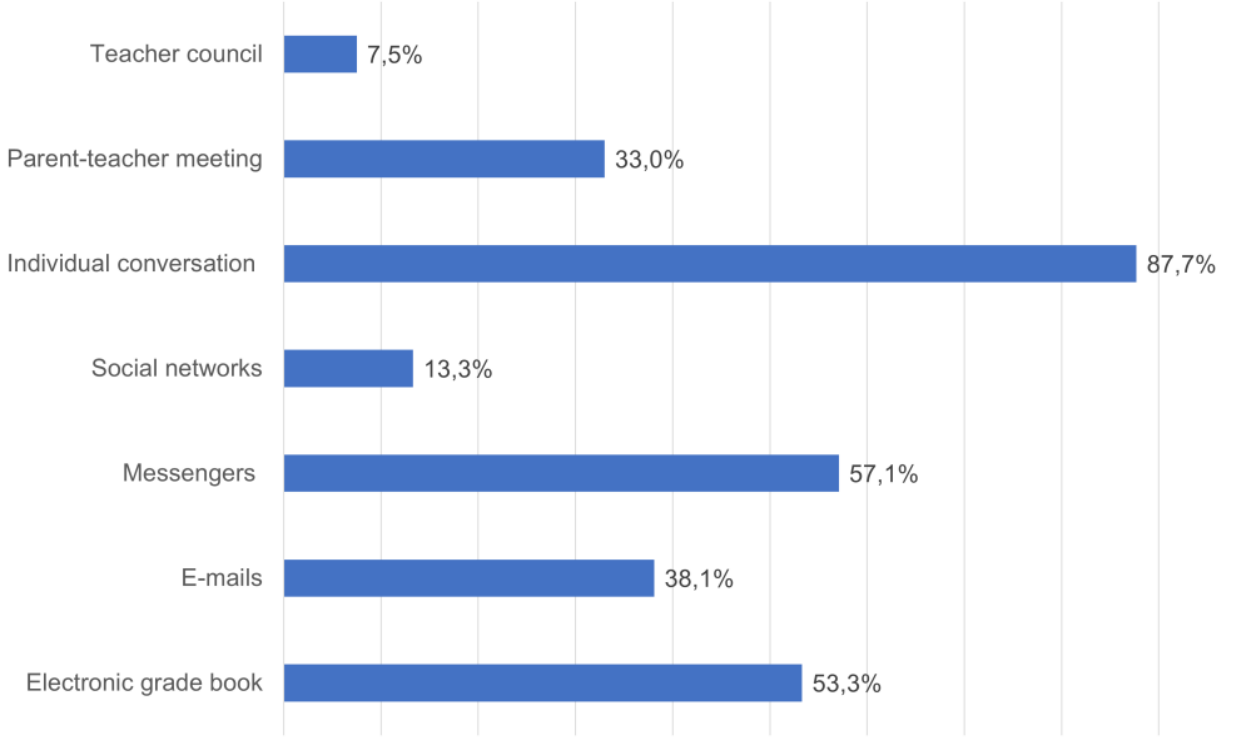

Fig. 1. Types of feedback in educational activities. 
Thus, individual conversation remained the most popular among the respondents; however, teachers cannot instantly communicate with all the students within one lesson. Therefore, other interactive forms of instant, regular, and modern communication are important, which are familiar to modern children, for example, messengers, social networks, and digital tools. The teacher's feedback with detailed comments follows the answers of advanced students, but the rest do not receive it.

One of the criteria for improving the quality of educational activities is teachers' mastering of modern educational and digital technologies. By analyzing the data from the responses, a consistent pattern can be determined. The respondents rarely gave tasks connected with individual projects and research, but they often used quizzes, answers at the blackboard, independent work, and work in pairs. The respondents indicated the need to improve competencies in the implementation of such technologies as mind maps, case studies, gaming, distance educational technologies, technologies for the development of critical thinking, problem learning, tutoring, working with children with disabilities, personalized learning, project activities, and others.

The data obtained with the help of the 2015-2017 survey, which involved school teachers helped to determine the level of proficiency in innovative technologies and various means of the information and educational environment. $35 \%$ of the respondents were familiar and knew how to use them; $56 \%$ did not know very well how to use them $[13,14$, $15]$.

The authors of the study stated a tendency towards the development of teachers' unwillingness to implement educational activities in the digital educational environment. The rapid development of digital technologies determines the need to create such an environment for the development of a child, which will contribute to the accessibility of education, formation of motivation, organization of feedback, and improvement in the quality of education.

\section{Discussion}

The results of the study and the experience of skill development and further training programs for teachers made it possible to identify five key areas of their professional gaps in the field of digital literacy and organization of distance learning. They include the digital educational environment and using open educational resources; using digital technologies in the organization of educational activities; methods and techniques of organizing feedback; pedagogical communication in the digital environment; information security and ethics in the digital environment. The presented blocks are considered to be active zones of professional development, where the professional skill of teachers will constantly change under the influence of new technologies and the degree of readiness of their use in educational activities, which leads to the need for continuous self-development and selfeducation of teachers.

The important conditions for professional development in the processes of skill development, further training, and self-education are: creation of a personal educational product using various digital tools and services; active interaction with colleagues in the process of experience exchange and creating educational products and methods of using digital technologies in teaching; priority of digital tool quality over quantity, therefore, mastering the criteria for choosing digital tools for solving specific pedagogical problems, taking into account the capabilities and limitations of each of these tools, becomes an important aspect; any educational process of professional development and its results (products) leave "digital footprints", which can not only be used in educational activities by all teachers but can also lead to the creation of a system for recognizing the informal results of additional professional education. 
Based the presented zones of professional development of teachers at the Moscow City University in 2020, the following educational programs were created and implemented:

a) professional retraining: "Distance learning techniques" (48 hours) for teachers of the Novgorod region (in cooperation with the firm "Humanitarian Projects 21 st Century"),

b) skill development and further training: "Distance learning techniques using educational resources of the Moscow Electronic School" (18 hours) for Moscow teachers' mass training to work in a digital educational environment (more than 3,000 students), "Organization of student activities using distance learning technologies" (36 hours), which introduced teachers to the digital technologies and electronic environments for solving learning problems,

c) skill development and further training: "Effective communication and productive interaction techniques", "The use of digital means for the development of creative thinking of students", "Digital means of communication with students", "Techniques for the use of digital media in the organization of educational activities of students" (16 hours), intended for the sharing of Russian experience with the foreign teachers (the projects of the Federal Agency for the Commonwealth of Independent States Affairs, Compatriots Living Abroad, and International Humanitarian Cooperation).

\section{Conclusion}

Thus, the activation of professional development processes based on the detection of professional gaps and personalized skill development and further training (primarily, through mechanisms for the individual overcoming of digital illiteracy) will accelerate the digital transformation of a modern school and create conditions for the elimination of the digital divide of the population.

It seems that the problem of preparing teachers for the use of digital technologies in educational activities soon will be associated with diagnostic tools that allow each teacher to assess their professional gaps and build long-term plans for professional development in key areas, as well as with the construction of a digital platform for discussion and recognition of digital competencies of teachers by the expert pedagogical community.

\section{References}

1. A.M. Kondakov, A.A. Kostyleva, RUDN Journal of Informatization in Education 16(4), 295-307 (2019). https://doi.org/10.22363/2312-8631-2019-16-4-295-307

2. S. Tejasvee, D. Gahlot, R. Poonia, M. Kuri, Lecture Notes in Networks and Systems, 135 (2021). https://doi.org/10.1007/978-981-15-5421-6_31

3. E.V. Frolova, T.M. Ryabova, O.V. Rogach, European Journal of Contemporary Education, 8(4), 779-789 (2019). https://doi.org/10.13187/ejced.2019.4.779

4. S.M. Lesin, D.A. Mahotin, V.Yu. Mikhailov, Inostrannye yazyki v shkole [Foreign languages at school], 9, 5-14 (2020)

5. E.N. Kukso, Desyat' effektivnykh sposobov uluchsheniya kachestva prepodavaniya $\mathrm{v}$ shkole [Ten effective ways to improve the quality of school teaching] (Sentyabr, Moscow, 2016)

6. Yu.A. Lyakh, Yaroslavskii pedagogicheskii vestnik [Yaroslavl Pedagogical Bulletin], 2, 8-16 (2018)

7. E.Y. Ignateva, Lifelong education: the 21 st century, 3(23), 71-83 (2018)

8. K.A. Bessonov, Juvenis scientia, 2, 86-89 (2016) 
9. M.K. Baisalbaeva, G.S. Syzdykova, Molodoi uchenyi [Young Scientist], 6, 198-201 (2019)

10. O.N. Shapovalova, N.F. Efremova, Pedagogy. Theory \& Practice, 5(1), 1-8 (2020). https://doi.org/10.30853/pedagogy.2020.1.1

11. V.I. Blinov, E.Yu. Esenina, I.S. Sergeev, Professionalnoe obrazovanie i rynok truda [Vocational education and labor market], 3, 4-18 (2019)

12. V.P. Smorchkova, Rol supervizii v formirovanii professionalno-lichnostnykh kachestv budushchego pedagoga [The role of supervision in the formation of professional and personal qualities of a future teacher], in Pedagogicheskoe obrazovanie: vyzovy XXI veka. Scientific works compilation from the All-Russian scientific-practical conference dedicated to academician V.A. Slastenin, Ministry of Science and Higher Education of the Russian Federation, 26-27 September, Novosibirsk, Russia, 149-152 (2019)

13. N.N. Sheveleva, E.V. Chernobai, Pedagogika [Pedagogy], 10, 95-103 (2018)

14. E.N. Gevorkyan, A.N. Ioffe, M.M. Shalashova, Pedagogika [Pedagogy], 1, 74-86 (2020)

15. M.L. Agranovich et al., Rossiiskie uchitelya v svete issledovatelskikh dannykh [Russian teachers in the context of research data] (National Research University Higher School of Economics, Moscow, 2016) 